\title{
New Institutionalism Politics: Integration of \\ Old Institutionalism and Other Methodologies
}

\author{
Yuxin $\mathrm{Wu}$ \\ School of Public Administration, Zhejiang Gong shang University \\ Hangzhou 310018, China \\ E-mail: yuxin2595@sina.com
}

\begin{abstract}
In the process of transition from old institutionalism to new institutionalism, theoretical foundation of old institutionalism was gradually enlarged and more research approaches were integrated. Firstly, rational aspects of behavioristic politics as borrowed. Then, its epistemology, its research target and research level are expanded. Finally, relevant theories of economics, sociology and history are absorbed. At last, a new school in political science is formed on the basis of integration with several methodologies, namely, new institutionalism politics.
\end{abstract}

Keywords: Institutionalism, New institutionalism, Methodology, Integration

With continual development of politics theory, its methodology is also being improved incessantly. More theoretical hypothesis and research tools bring into existence a flourishing sight. Transition from old institutionalism into new institutionalism politics is more an outcome of integration of institutionalism with other research methods on the basis of criticizing its own defects than improvement of research methods of institutionalism. The article of $<<$ New Institutionalism: Organizational Factors in Political Life >> by March \& Olsen symbolizes formal birth of new institutionalism politics. In this article, they point out, "In classical theories of earlier politics, the old institutionalism did exist". However, old institutionalism and new institutionalism differed from each other, so it would be much accurate to describe the latest thought as integration of old institutionalism factors with non-institutionalism features in the latest politics." That is to say, new institutionalism is an outcome of integration of old institutionalism with various research methods in politics.

\section{Major viewpoints of new institutionalism methodology}

Since March \& Olsen formally applied the phrase of "new institutionalism", different understanding of new institutionalism in institutionalism has largely enhanced our understanding in the political world. Major viewpoints of new institutionalism methodology include the following. (1) Emphasis on importance of institutionalism, and understanding of political life from the perspective of institutionalism, which makes political life the center of politics research again. (2) At the time of emphasizing importance of institutionalism, analysis on personal preference and behavior is added. (3) It revises negligence of behaviorism on political value, attaches importance to substantive justice of institutionalism and procedure itself, and focuses on analysis and judgment on "positive" institutionalism. (4) It determines the core status of institutionalism analysis method, but has neglected neither interests and strategies of political behavers, nor distribution of power among them. On the contrary, it places these factors into a specific context, and reveals relations between these factors by observing ways of establishment of a political context. Therefore, by placing structured factors into the central position of analysis, institutionalism analytical method can enable theoretical practitioners to grasp the complexity of an actual political situation, but not at the cost of sacrificing clarification of a theory. (5) According to new institutionalism politics, not only history affects institutionalism, but what's more, institutionalism affects history, and it is institutionalism, but not an individual, that is the primary target of political science research. That, to a great extent, facilitates our understanding in institutionalism and the historical progress of institutionalism development.

\section{Feasibility and necessity analysis on integration of institutionalism methodology with other methodologies}

\subsection{Institutionalism is the fundamental method of politics research}

It ought to be said that, before institutionalism became the fundamental method of politics research, politics couldn't be 
seen as an independent discipline, but at most a subdiscipline of philosophy. Just as we learn from Russell's $<<$ A History of Western Philosophy $>>$, those who are called great politicians all occupy an important position in this masterpiece of exposition on philosophers. Therefore, as Fritz Eckstein said, if politics was to become an independent discipline, it had to differentiate itself from philosophy, plutonomy and even sociology, and then it should emphasize study on formal institution of law. That is to say, determination of institutionalism research method has enabled politics to break away from entanglement of philosophy (or political philosophy), plutonomy and even sociology, and to become an independent discipline. However, the reason plutonomy can become a method or can separate politics from philosophy is that it satisfies the following three conditions. Firstly, it has a definite research subject or issue field, which is a formal legal institutional framework, including constitution, public law, and formal institutional structure, etc. Secondly, it has its own research route and method system, and its methodology characteristics is a historical, comparative, textuary, descriptive and inductive logic and method. Thirdly, it has its own academic school, and before the birth of behaviorism politics, what political researchers believe in is mainly politics of this institution analysis. Therefore, research method of institutionalism can be regarded as the fundamental method of political research. So far, institutional orientation has always been proving perfect service for political science. And institutionalism methodology has the realistic foundation to be integrated with other methods.

\subsection{Perfect compatibility of institutionalism methodology}

Perfect compatibility also contributes to the fact that institutionalism has become the fundamental method of political research. Institutional research not only illustrate mechanically mandatory rules of constitutional government system, but precisely analyzes the following issues: what kind of institution it is, what kind of institution it should be, why such an institution is chosen or formulated, which experiences are obtained in practical operation, which disadvantages and what to be improved, what's the relation between these legal institutions and institutions out of the law, and how to conduct the reform. As a matter of fact, institutional research is far from the above mentioned. For example, we can study which institutions are carried out or implemented in practice, and which are not, and then do further research on reasons underlying. Also, because political institution has the feature of periodic transformation, and institutional patterns at different historical periods are different, when we elaborate criteria of institution, we can make a comprehensive study on criteria of institution at different periods and their actual functioning conditions by means of historical comparison, and explore underlying changing rules. That is to say, institutional study does not exclude historical study, process study, empirical study and behavioral study, etc. Actual functioning of institution is behavior or fact. Without this dynamic or process study, a factual and realistic resolution to issues in institutional study is unlikely. Therefore, it is believed that there exists great compatibility between institutional study and process \& empirical study, which makes it possible to integrate institutionalism with other research methods.

However, due to various reasons, there lack profound feelings towards this compatibility among scholars who are engaged in political research, which makes it more difficult to carry out the compatibility in practice. Most achievements are limited to citations of or explanation about laws or regulations, and are not combined with empirical study and other research methods. Therefore, there exist a great many problems in the practical operation of research methods of institutionalism.

\subsection{Limitations of institutionalism methodology}

Methodology of traditional institutionalism also has certain limitations in its analysis on practical issues in political operation. First of all, description of institution study and orientation of inductive logic results in possibility of negligence of the formation of a policy and operation process of the authority. Then, institutionalism overemphasizes formal institution of law and its historical background, but neglects influence of informal institution on decision-making and exercise of a power. Finally, it is the state that institutionalism is centered with, but not the society, and it is the static politics of descriptive orientation, but not problem analysis orientation.

Defect of research method of old institutionalism results in the realistic requirement of institutionalism to be changed and causes the inevitability of integration of institutionalism with other research methods. Besides, institutionalism has perfect compatibility, so new institutionalism in politics finally emerged again after institutionalism methodology absorbed the newly developed behaviorism politics in 1970s, and this renaissance was exactly an outcome of integration of institutionalism with several other methodologies. Of course, in the process of integration, behaviorism became an important theoretical source of new institutionalism methodology.

\section{Significant theoretical source of integration from old to new institutionalism: behaviorism}

In the transition from old institutionalism to new institutionalism, institutionalism and many methodologies of politics penetrate and affect each other, but it is behaviorism methodology that has the greatest effect upon institutionalism, and behaviorism is an important theoretical source of new institutionalism methodology. Behaviorism revolution in 1940s changed institutional tradition in politics study, in which significance of political institution became increasingly lessened and was nothing more than "the stage for occurrence of a political behavior". According to Dahl. Waldo and 
Easton etc, behaviorism in politics is a political thought and movement which explains a political phenomenon by means of observed behavior and which attempts to turn politics into an actual science. Its central credendum is to mould politics according to methodology and model of natural science. Behaviorism politics has its success and rationality, which is as follows. (1) Centered with political behavior of human being, behaviorism politics brings into study scope of politics psychological, social, economic and cultural factors, which widens study object of politics. (2) Under the slogan of "science", behaviorism politics studies political behavior by means of various theories and methods, and afterwards, analysis methods of the following technical levels are extensively applied: case analysis, experimental analysis, simulation analysis, investigation and study, factor analysis, statistical analysis and system analysis, etc. (3) Comprehensive application of theories and methods of natural science and other social sciences brings new conclusions to behaviorism politics which traditional politics doesn't have, such as Systems Approach, structure-function theory and Decision Theory, etc, which are achievements of behaviorism politics. The research method of behaviorism politics which is centered with behavior of human being enable people to further re-consider shortcomings of old institutionalism politics and enlarge field of view of politics study. Therefore, it is believed that, in the transition from old institutionalism to new institutionalism, behaviorism acts as the important theoretical source. After absorbing advantages of behaviorism, institutionalism emerges in the form of new institutionalism at last.

\section{Concrete process of integration}

\subsection{Expansion of epistemology}

In the process of integration, epistemology of institutionalism is gradually expanded, more comprehensive and with more inclusivity. Specific analysis is as follows: according to old institutionalism, institution brings about behavioral and individual preference. Behavioral pattern of individuals and collectives can be presupposed, while law and institution are presupposition forms of the behavioral pattern, and institution changes this presupposition into an organizational structure and power relation. Therefore, analysis on institution of law can presuppose behavioral pattern of individuals or collectives. On the contrary, according to new institutionalism, institution and behavior of human being are interactional and interactive. That is to say, "behavior and institution" are attached equal importance. Under such a theoretical hypothesis, there emerge two significant theoretical schools in new institutionalism. The first school is rational choice institutionalism, which supports the hypothesis of economic man in economics theory, and believes that, starting from the perspective of individualism, all social or collective phenomena, such as institution, etc, can be explained based on individual behavior. Hence, institution is an outcome of individual interaction, and whether from the perspective of strategic design or maximization of self interest, it is supposed that individual behavior is prior to institution. The second school is sociological institutionalism, which borrows research method of sociology and starts from organicism to concentrate on significance of social criterion and social value that have effects on individual behaviors, and which investigates how social power (institution and social customs, etc) affects individual behaviors. According to the latter school, institution is prior to individuals. Due to its more extensive understanding in the relation between institution and behavior of human being, new institutionalism has more comprehensive connotation. New institutionalism is established based on more clear-cut and complicated theoretical framework, which endows it with stronger vitality.

\subsection{Enlargement of study object}

New institutionalists believe that, major behavers of modern political, economic and social life should be various formal organizations. However, institution is no longer equal to a political organization, and institution is also understood as such informal institutions as customs, habits, beliefs and conventions which are formed during people's long-term activities, and is even explained as a culture by the school of sociological institutionalism, so understanding of political institution is broadened and deepened. According to new institutionalists, informal institutionalism can strengthen formal institution, and sometimes, informal conventions may dominate formal institutions. Therefore, study object of new institutionalism not only includes formal institution, but includes informal institution.

\subsection{Diversification of study level}

During old institutionalism, scholars were mainly committed to study on formal institution of the government and on relevant constitutional documents or law. For example, they applied historical comparative method, descriptive and inductive method and formal law method to discuss the nation, sovereignty, constitutional government system and federal system, etc. On the contrary, new institutionalists borrow public choice theory, rational choice theory, organizational theory and social and capital theory in economics and sociology to explain organizational phenomena of intermediate level (such as department, secondary department and group decision-making, etc), and individual behavior of micro-level (such as rational calculation). Therefore, new institutionalism not only compares and describes political institution from the overall perspective, but more analyzes influences of institution on political behavers of different levels from the perspective of intermediate level and micro-level, such as labor and capital structure, relations between governments and labour organizations etc. Therefore, combination of dynamic and static study is advocated in the process of study. 
All in all, compared with old institutionalism, new institutionalism is indeed a brand-new institutional theory. Its epistemology with more inclusivity, more extensive study object and more diversified study level not only broaden connotation and denotation of institution, but also improve explanation power of institutional study by absorbing theoretical systems in economics and sociology, etc. In addition, it also enables institution to regress to the field of view of most politicians and promotes integration of politics methodology.

\section{Conclusion: new institutionalism is an outcome of integration of old institutionalism with other methodologies}

Interdisciplinary integration is the trend of contemporary social science development, and new institutionalism also embodies its attempt towards this trend. Therefore, appearance of new institutionalism politics is not only criticism for ignorance of behaviorism politics on institutional study, but response of social sciences to institution, such as economics. Then, on the basis of criticizing behaviorism and inheriting traditional institution study, and on the basis of absorbing and modifying economics, sociology and history, the institutional analysis paradigm by Aristotle was finally integrated with several methodologies to generate a new school in political science --- new institutionalism politics.

As a matter of fact, pure institutional study doesn't exist. Therefore, the research method of new institutionalism is generated by means of modifying research method of old institutionalism and successfully borrowing research methods of various relevant disciplines. That is to say, research method of new institutionalism is an outcome of integration of old institutionalism with several methodologies. In this meaning, it is no longer a unitary methodology. Just as Peters said, new institutionalism is seen as "broad, yet diversified direction of political study", and they are assembled together by the assertion that "institution is a variable to explain most political life and it is a factor which also needs to be explained".

\section{References}

Chen, Zhenming. (1999). Politics. China Social Sciences Press, 57-58.

Guo, Zhenglin \& Xiao, Binzhu. (2003). Norm and Empirical Research Method. Guangdong Peoples Publishing House, 2 .

Huang, Xinhua. (2005). New Institutionalism in Political Science --- Comments on New Institutionalism Politics in Contemporary Western Countries. The Fourth Quarter Political Subject of NPC National People's Congress.

$\mathrm{Pu}$, Xingzu. (1999). Political System of People's Republic of China. Shanghai People's Publishing House, 49-50.

Xue, Xiaoyuan \& Chen, Jiagang. (2004). Globalization and New Institutionalism. Social Sciences Academic Press, 179. 